\title{
Correction to: Influence of Biochar from Slow Pyrolysis on Dissolved Organic Carbon and Total Dissolved Nitrogen Levels of Urban Storm-Water Runoff
}

\author{
Enrico Mancinelli (iD • Edita Baltrènaitė • Pranas Baltrėnas • \\ Raimondas Grubliauskas • Eglè Marčiulaitienė • Giorgio Passerini • \\ Mantas Pranskevičius
}

Published online: 30 July 2018

(C) Springer Nature Switzerland AG 2018

\section{Correction to: Water Air Soil Pollut}

https://doi.org/10.1007/s11270-018-3896-9

In the original publication, the numbers 289 and 290 were added in Table 1 footnote. The table footnote should read "Flow-rates are shown as the mean value $(n=5) \pm$ standard deviation. USWR urban storm-water runoff'.

The original publication was updated.

The online version of the original article can be found at https://doi.org/10.1007/s11270-018-3896-9

\section{E. Mancinelli $(\bowtie) \cdot G$. Passerini}

Department of Industrial Engineering and Mathematical Sciences, Univeristà Politecnica delle Marche, via Brecce Bianche 12, 60131 Ancona, Italy

e-mail: e.mancinelli@pm.univpm.it

E. Baltrènaitè · P. Baltrènas · R. Grubliauskas •

E. Marčiulaitienè $\cdot$ M. Pranskevičius

Institute of Environmental Protection, Vilnius Gediminas, Technical University, Saulètekio Av 11, LT-10223 Vilnius, Lithuania 